
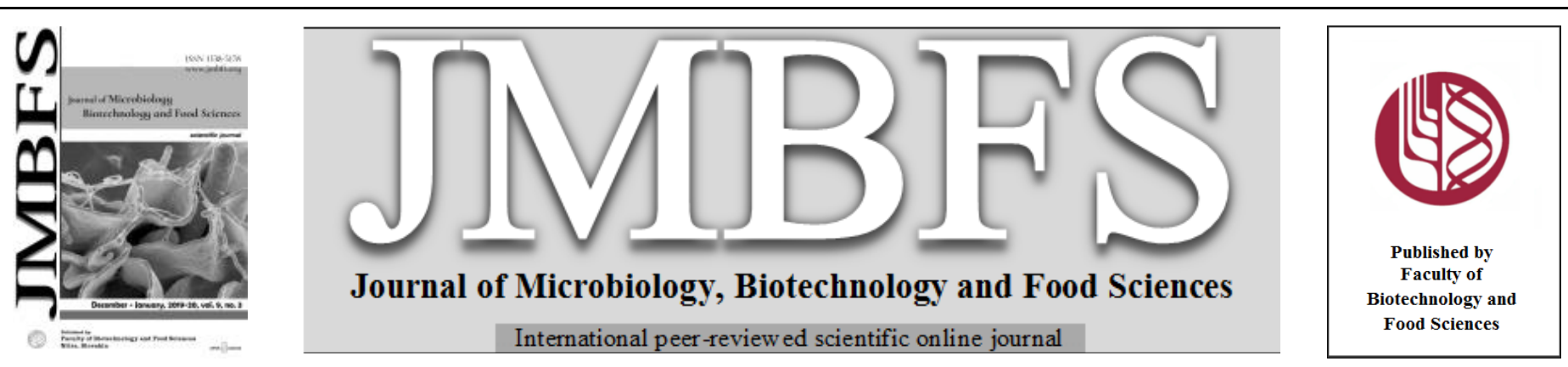

\title{
THE RELATIONSHIP BETWEEN RISK ELEMENTS CONTAMINATION OF WILD EDIBLE MUSHROOMS (BOLETUS RETICULATUS SCHAEFF.) AND UNDERLYING SOIL SUBSTRATE
}

\author{
Ivona Jančo*l, Marek Šnirc ${ }^{1}$, Miroslava Hrstkovál, Ivana Tirdil'ovál , Tomáš Lošák², Július Árvay ${ }^{l}$
}

Address(es): Ing. Ivona Jančo,

${ }^{1}$ Slovak University of Agriculture in Nitra, Faculty of Biotechnology and Food Sciences, Department of Chemistry, Tr. A. Hlinku 2, 94976 Nitra, Slovak republic, phone number: +421 376414111.

${ }^{2}$ Mendel University in Brno, Faculty of Regional Development and International Studies, Department of Environmentalistics and Natural Resources, tr. Generála Píky 7, 613 00, Brno, Czech Republic, phone number: +420 545136256.

*Corresponding author: xjanco@is.uniag.sk

doi: 10.15414/jmbfs.2019/20.9.3.657-660

\section{ARTICLE INFO}

Received 1. 8. 2019

Revised 8. 10. 2019

Accepted 15. 10. 2019

Published 1. 12. 2019

Regular article

open ${ }_{\text {ACCESS }}$

\begin{abstract}
Wild growing mushrooms have been a popular delicacy in many countries. Some species, especially from genus Boletus accumulate high levels of risk elements. Boletus reticulatus is one of the favorite and most consumed mushrooms in Slovak republic. Fruiting bodies of $B$. reticulatus (48 samples) and forest underlying soil substrates (48 samples) were collected and analyzed for $\mathrm{Cd}, \mathrm{Pb}$ and $\mathrm{Hg}$ contents in pine stands of 8 different locations in eastern and central Slovak republic. ICP-OES (Optical emission spectrometry with inductively coupled plasma) analysis revealed the presence of 22 macro- and micro elements in mushroom and soil samples, of which we evaluated cadmiumand lead in this research. Mercury was determined by Advanced Mercury Analyzer (AMA-254). Subject to mushroom samples, caps and stems were analyzed separately. In mushroom stems, pursuant to the supreme average value, highest amount of $\mathrm{Cd}$ was $2.63 \mathrm{mg} \cdot \mathrm{kg}^{-1} \mathrm{DW}, \mathrm{Pb}: 6.04 \mathrm{mg} \cdot \mathrm{kg}^{-1} \mathrm{DW}$ and $\mathrm{Hg} 0.72 \mathrm{mg} \cdot \mathrm{kg}^{-1} \mathrm{DW}$. In mushroom caps the highest average concentration was for Cd: $6.45 \mathrm{mg} \cdot \mathrm{kg}^{-1} \mathrm{DW}$, for Pb: $3.73 \mathrm{mg} \cdot \mathrm{kg}^{-1} \mathrm{DW}$ and for $\mathrm{Hg}: 1.39 \mathrm{mg} \cdot \mathrm{kg}^{-1} \mathrm{DW}$. Comparing the results with the limits of the European Union (EU) (Cd: $0.50 \mathrm{mg} \cdot \mathrm{kg}^{-1} \mathrm{DW}, \mathrm{Pb}: 1.00 \mathrm{mg} \cdot \mathrm{kg}^{-1}$ DWand $\mathrm{Hg}: 0.75 \mathrm{mg} \cdot \mathrm{kg}^{-1} \mathrm{DW}$ ) for edible mushrooms, $50 \%$ $(\mathrm{Pb}), 40 \%(\mathrm{Hg})$ and $100 \%(\mathrm{Cd})$ of mushroom caps samples exceeded the limits.In case of mushroom stems, $75 \%(\mathrm{Cd})$ and $38 \%(\mathrm{~Pb})$ of the samples exceeded the EU limits, while regard to $\mathrm{Hg}$ none of the mushroom stem samples exceeded the limit. The results showed that the values of the studied elements in soil underlying substrate increased in the order: $\mathrm{Hg}\left(\mathrm{ND}-0.14 \mathrm{mg} \cdot \mathrm{kg}^{-1} \mathrm{DW}\right)<\mathrm{Cd}(2.09-33.5 \mathrm{mg} \cdot \mathrm{kg}$ $\left.{ }^{1} \mathrm{DW}\right)<\mathrm{Pb}\left(12.5-57.5 \mathrm{mg} . \mathrm{kg}^{-1} \mathrm{DW}\right)$. Based on this, it can be stated that the monitored areas of 8 locations in Slovak republic represent an increased risk of selected elements into the above ground parts of mushrooms and as such pose a risk to human health.
\end{abstract}

Keywords: Wild edible mushrooms, Boletus reticulatus, Soil, AMA 254, ICP-OES

\section{INTRODUCTION}

The investigation on the beneficial properties of wild edible mushrooms has gained attention by the scientific community during the last decades (RonceroRamos et al., 2017). Wild growing edible mushrooms are a popular delicacy in many countries in the world.The consumption and collecting of wild edible mushrooms is increasing, due to a good content of proteins as well as a higher contentof minerals. Mushrooms are a separate group of live organisms of considerable nutritive, pharmaceutical and ecological value.They are ubiquitous in nature and play an important role in forest ecosystems because they can biodegrade the substrate (Liu et al., 2016). Fruiting bodies of mushrooms are appreciated, not only for texture and flavour but also for their chemical and nutritional characteristics. Mushrooms are valuable healthy and nutritious foods, low in calories and high in vegetable proteins, vitamins, iron, zinc, selenium, sodium, chitin, fibres and minerals. In general, the fruiting bodies of mushrooms, on dry weight basis, contain about $56.8 \%$ carbohydrate, $25.0 \%$ protein, $5.70 \%$ fats and 12.5\% ash (Ouzouni et al., 2009).Accumulation of risk elements by mushrooms has been known for a few decades and several works describing metal content in fruit bodies have been published. The element concentrations are primarily species dependent (Işıloğlu et al., 2001). Risk elements are one of the main sources of pollution in the environment, since they have a significant effect on its ecological quality. Human activity leads to increasing levels of risk element contamination in the environment. Risk elements owing to atmospheric and industrial pollution accumulate in the soil and influence the ecosystem nearby. Mushrooms could uptake different metallic elements from soil and accumulate them. In this condition, the mushroom will be toxic and non-edible (Bahadori et al., 2019). Soil is a critical environment because it can accumulate pollutants produced by anthropogenic activities, such as mining and processing of ore, industry, agriculture, traffic, etc.The transport of heavy metals in soil is the result of processes between soil and metal components, which include processes of physical, chemical, and biological nature. However, soil is not only a passive acceptor of heavy metals, polluted soils become a source of contamination for other environmental components and the food chain (Demková et al., 2017). The determination of risk element in soil samples is very important in monitoring the environmental pollution and cadmium, lead and mercury are a representative trace metals whose levelsin the environment represent a reliable index of environmental pollution (Tüzen 2003). Compared to green plants, mushrooms can build up large concentrations of some risk elements, and a great effort has been made to evaluate the possible danger to human health from the ingestion of the mushrooms (Ouzouni et al., 2009).Species of the genus Boletus can accumulate several fold greater amounts of risk elements, than in fruit and vegetables.Boletus reticulatus is an ectomycorrhizal edible mushroom, which usually grows up under the mixed deciduous coniferous forests, especially in symbiosis with oak (Quercus $s p$.), beech (Fagus sylvatica), hornbeam (Carpinus betulus) and chestnut (Castanea sativa). The fruiting body of Boletus reticulatus consists of cap and stem. The cap with brown in color is 8 to $30 \mathrm{~cm}$ in diameter and the stipe is light brown color, 5 up to $20 \mathrm{~cm}$ tall (Širić et al., 2016).

The aim of this study was to determinate the amounts of selected risk elements in Boletus reticulatus and underlying soil substrate,and then to examine the relationship between mushrooms and underlying soil substrate.

\section{MATERIAL AND METHODS}

Study areas, sampling and sample preparation

In foraging season September - November 2017, the fruiting bodies of Boletus reticulatus were collected from 8 different locations (Dobroč, Kokošovce, Kolačkov, Malý Lipník, Nižné Ružbachy, Orava-Bobrov, Sitnianska Lehôtka and Suchý vrch) in Slovak republic. Kokošovceand Suchý vrch belong to the $2^{\text {nd }}$ environmental quality - regions with moderately disturbed environment. Another six locations (Dobroč, Kolačkov, Malý Lipník, Nižné Ružbachy, Orava-Bobrov and Sitnianska Lehôtka) belong to the $1^{\text {st }}$ environmental quality - regions with undisturbed environment. The identification of the sampling areas was 
performed using the GPS coordinates. All mushroom samples, directly after pickup, were cleaned up from any organic and inorganic debris and the bottom part of stem was cut-off. After, they were divided into two parts - cap and stem. As individual cap and stem samples, they were sliced into pieces and dried until the dry weight (DW) at $45{ }^{\circ} \mathrm{C}$ in laboratory heat-dryer (Memmert Hot air oven UN110, Germany). Finally, they were pulverized and stored in polyethylene bags until

the further analysis. Soil samples were taken from the same location as mushrooms, from a depth of approximately $0-10 \mathrm{~cm}$. The samples were dried for several weeks, then sieved through a pore size of $2 \mathrm{~mm}$ and stored in paper bags until analysis

\section{Samples analysis}

Total mercury concentration was determined by cold-vapour AAS analyzer 254 (Altec, Czech Republic), separately in 48 samples of caps, steams and underlying soil substrate (144 samples in total).

The mineralization was performed by using the pressure microwave digestion system (Ethos One, Milestone, Italy) in a mediumof $5 \mathrm{~mL}$ of concentrated nitric acid (69\%, trace purity) and $1 \mathrm{~mL}$ of hydrogen peroxide (30\%, trace purity) with addition of $1 \mathrm{mLDI}$ water (deionized). The samples of biological material thus prepared were qualitatively and quantitatively analyzed by inductively coupled argon plasma emission spectrometry (ICP-OES) on an Agilent ICP-OES 720 (Agilent Technologies, Germany).

\section{Statistical analysis}

Descriptive statistic was used to characterize the data. MS Excel version 2013 was used to calculate average, SD, minimum and maximum values for each sample. XLSTAT (Addinsoft, 2014) was used to perform the Spearman's Rank correlation coefficient to determinatethe relationship (negative or positive) between tested variables, soil substrates and mushrooms, with a significant level $\mathrm{p}<0.05$.

\section{RESULTS AND DISCUSSION}

\section{Underlying soil substrate}

Data that we have obtained from statistical analysis for cadmium, lead and mercury in soil are shown in Table 1. According to Law no. 220/2004 of Slovak republic, limit value in soil for $\mathrm{Cd}$ is $0.70, \mathrm{~Pb} 70.0$ and $\mathrm{Hg} 0.50 \mathrm{mg} . \mathrm{kg}^{-1} \mathrm{DW}$.
The cadmium content in soil varied from 2.09 to $33.5 \mathrm{mg} \cdot \mathrm{kg}^{-1} \mathrm{DW}$. In case of average values, the highest content of cadmium was in Suchý vrch $\left(21.3 \mathrm{mg} . \mathrm{kg}^{-1}\right.$ DW) and the lowest in Orava - Bobrov (3.12 mg.kg-1 DW). Comparing average values with the admissible limit $\left(0.70 \mathrm{mg} \cdot \mathrm{kg}^{-1} \mathrm{DW}\right)$ all soil samples exceeded this limit. We noticed that the measured concentrations of $\mathrm{Cd}$ were a few tenth higher, when compared with the limit value. Values were within the range of 12.5-57.5 mg. $\mathrm{kg}^{-1} \mathrm{DW}$ for $\mathrm{Pb}$ and $0.00-0.14 \mathrm{mg} . \mathrm{kg}^{-1} \mathrm{DW}$ for $\mathrm{Hg}$.

The highest $\mathrm{Pb}$ average amount was detected in Nižné Ružbachy $\left(36.5 \mathrm{mg} \cdot \mathrm{kg}^{-1}\right.$ DW) and the lowest in Kokošovce (48.6 mg. $\mathrm{kg}^{-1} \mathrm{DW}$ ). Considering average $\mathrm{Hg}$ concentrations, the highest were detected in Kokošovce, Kolačkov, Malý Lipník and Nižné Ružbachy(0.03 mg.kg $\left.{ }^{-1} \mathrm{DW}\right)$ and the lowest (ND) in Sitnianska Lehôtka. Regarding to $\mathrm{Pb}$ and $\mathrm{Hg}$, all the analyzed soil samples were under the detection limit ( $\mathrm{Pb}: 70.0$ and $\mathrm{Hg}$ : $0.50 \mathrm{mg} \cdot \mathrm{kg}^{-1} \mathrm{DW}$ ).

Angelovičová and Fazekašová (2014) did a research which was conducted in Rudňany village, which belongs to the most polluted, environmentally loaded and unhealthy areas of Middle Spiš, Slovakia. A set of 24 soil samples from 8 locations were measured on heavy metal content and then compared to the limit values for Slovak soils (Act No. 220/2004). Mercury concentrations in soil were

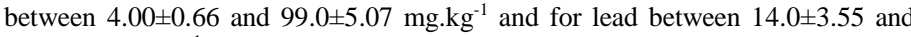
$102 \pm 4.54 \mathrm{mg} \cdot \mathrm{kg}^{-1}$. Ponds contain increased contents of lead due the processing of metal ores. Deposits of mercury sulphides became the main source of mining and processing activities, and therefore large amounts of mercury have been released to the environment, as an undesirable side effect. Melgar (2009) reported that the higher concentrations of mercury were observed with statistically significan differences in the terrestrial saprophytic species than in the mycorrhizal ones apart from the genus Boletus (in particular, B. pinophilus, which had one of the highest mean levels of mercury). These high mercury levels are due to the saprophytic species having higher decomposing activity and catalase activity. Falandysz et al. (2003) determined mercury concentrations in wild growing mushrooms (nine ediblesand 6 inedible species) and underlying soil. Among the analyzed edible mushroom species, the greatest concentrations of mercurywere quantified in the caps and stems B. edulis. Mercury concentrations in underlying soil substrate were between $2.70 \pm 1.20 \mathrm{ng}^{-g^{-1}} \mathrm{DW}$ $\left(0.03 \pm 0.00 \mathrm{mg} \cdot \mathrm{kg}^{-1} \mathrm{DW}\right)$ and $37.0 \pm 5.00 \mathrm{ng} \cdot \mathrm{g}^{-1} \mathrm{DW}\left(0.04 \pm 0.01 \mathrm{mg} \cdot \mathrm{kg}^{-1} \mathrm{DW}\right)$. Apart from the genetic features, which influence the accumulation of mercury, some ecological and environmental factors also influence the uptake and bioaccumulation. As has been indicated in some other studies, a key factor determining mercury abundance in fruiting bodies is the degree of substrate (soil) contamination.

Table 1 Cadmium, lead and mercury contents in underlying soil substrate $(n=48)$

\begin{tabular}{|c|c|c|c|c|c|c|}
\hline \multirow{2}{*}{ Locality } & \multicolumn{2}{|c|}{ Cd } & \multicolumn{2}{|c|}{$\mathbf{P b}$} & \multicolumn{2}{|c|}{$\mathbf{H g}$} \\
\hline & $\mathrm{AVG} \pm \mathrm{SD}$ & range & $\mathrm{AVG} \pm \mathrm{SD}$ & range & $\mathrm{AVG} \pm \mathrm{SD}$ & range \\
\hline Dobroč & $6.18 \pm 0.24$ & $(5.96-6.68)$ & $27.5 \pm 5.25$ & $(19.5-35.2)$ & $0.01 \pm 0.00$ & $(0.01-0.01)$ \\
\hline Kokošovce & $4.10 \pm 0.75$ & $(3.41-5.64)$ & $18.6 \pm 3.42$ & $(12.5-24.6)$ & $0.03 \pm 0.04$ & $(0.01-0.14)$ \\
\hline Kolačkov & $3.30 \pm 0.72$ & $(2.09-4.15)$ & $31.6 \pm 5.73$ & $(25.8-42.0)$ & $0.03 \pm 0.01$ & $(0.02-0.04)$ \\
\hline Malý Lipník & $3.46 \pm 0.77$ & $(2.62-4.69)$ & $33.5 \pm 11.0$ & $(21.0-47.4)$ & $0.03 \pm 0.01$ & $(0.01-0.04)$ \\
\hline Nižné Ružbachy & $3.47 \pm 0.72$ & $(2.55-4.51)$ & $36.5 \pm 16.3$ & $(18.7-57.5)$ & $0.03 \pm 0.01$ & $(0.02-0.05)$ \\
\hline Orava - Bobrov & $3.12 \pm 0.32$ & $(2.65-3.62)$ & $32.8 \pm 1.72$ & $(30.1-36.1)$ & $0.02 \pm 0.00$ & $(0.02-0.02)$ \\
\hline Sitnianska Lehôtka & $6.65 \pm 1.01$ & $(5.62-8.35)$ & $30.0 \pm 5.56$ & $(20.4-35.2)$ & ND & (ND-0.01) \\
\hline Suchý vrch & $21.3 \pm 6.77$ & $(14.5-33.5)$ & $23.2 \pm 7.92$ & $(14.8-34.4)$ & $0.02 \pm 0.01$ & $(0.01-0.03)$ \\
\hline
\end{tabular}

\section{Mushroom caps (Boletus reticulatus)}

The cadmium lead and mercury contents in the analyzed mushroom cap samples are given in Table 2 .

The concentrations of investigated risk elements in mushroom caps were found to be in the range of 1.00-10.6 mg. $\mathrm{kg}^{-1} \mathrm{DW}$ for Cd,ND-6.41 mg.kg ${ }^{-1} \mathrm{DW}$ for $\mathrm{Pb}$ and 0.01-2.02 mg. $\mathrm{kg}^{-1} \mathrm{DW}$ for $\mathrm{Hg}$. In case of average values, the highest content of cadmium was in Nižné Ružbachy $\left(6.45 \mathrm{mg} . \mathrm{kg}^{-1} \mathrm{DW}\right)$ and the lowest $(0.77 \mathrm{mg} . \mathrm{kg}$ $\left.{ }^{1} \mathrm{DW}\right)$ in Kokošovce. Comparing average values with the admissible limit $(0.50$ mg.kg-1 DW) all cap samples exceeded this limit.

The highest $\mathrm{Pb}$ average amount was detected in Kolačkov (3.73 mg. $\left.\mathrm{kg}^{-1} \mathrm{DW}\right)$ and the lowest in Dobroč $\left(0.21 \mathrm{mg} \cdot \mathrm{kg}^{-1} \mathrm{DW}\right)$. Considering average Hgconcentrations, the highest was detected in Malý Lipník (1.39 mg.kg-1 DW) and the lowest $(0.26$ mg.kg-1 DW) in Sitnianska Lehôtka. Regarding to admissible limit for $\mathrm{Pb}(1.00$ mg.kg-1 DW), 4 locations (Kolačkov 98\%, Malý Lipník 98\%, Nižné Ružbachy $100 \%$ and Suchý vrch $60 \%$ ) exceeded the limit, wherein for $\mathrm{Hg} 3$ locations (Kolačkov 97\%, Malý Lipník 83\% and Nižné Ružbachy 60\%) crossed the limit (0.75 mg.kg-1 DW)

The highest mean mercury levels of $6.90 \mathrm{mg} \cdot \mathrm{kg}^{-1} \mathrm{DW}$ (cap) and $3.30 \mathrm{mg} \cdot \mathrm{kg}^{-1}$ (stem) was found in B.edulis and B. pinophilus, respectively (Melgar et al. 2009). Komárek et al. (2007) did a research on young, medium and old mushroom fruiting bodies of B.edulis. They reported that the contents of $\mathrm{Pb}$ in this species reach up to $5.96 \mathrm{mg} \cdot \mathrm{kg}^{-1}$ in caps and $165 \mathrm{mg} \cdot \mathrm{kg}^{-1}$ in stems. Absorbing fact which they observed was that the older the mushroom is, the lead content is lower. This fact shows that the concentration of risk elements also depends on age. 
Table 2 Cadmium, lead and mercury contents in Boletus reticulatus caps $(\mathrm{n}=48$ )

\begin{tabular}{ccccccc}
\hline \multirow{2}{*}{ Locality } & \multicolumn{2}{c}{ Cd } & \multicolumn{2}{c}{ Pb } & \multicolumn{3}{c}{ Hg } \\
& AVG \pm SD & range & AVG \pm SD & range & AVG \pm SD & range \\
\hline Dobroč & $1.71 \pm 0.82$ & $(0.32-2.97)$ & $0.21 \pm 0.27$ & $(\mathrm{ND}-0.71)$ & $0.60 \pm 0.22$ & $(0.28-0.88)$ \\
Kokošovce & $0.77 \pm 0.29$ & $(0.31-1.24)$ & $0.47 \pm 0.32$ & $(0.15-1.17)$ & $0.45 \pm 0.14$ & $(0.25-0.70)$ \\
Kolačkov & $5.57 \pm 0.92$ & $(4.07-6.93)$ & $3.73 \pm 1.34$ & $(1.09-4.76)$ & $1.24 \pm 0.38$ & $(0.77-1.91)$ \\
Malý Lipník & $4.79 \pm 2.40$ & $(2.21-8.59)$ & $3.37 \pm 1.29$ & $(1.73-4.75)$ & $1.39 \pm 0.38$ & $(0.67-1.78)$ \\
Nižné Ružbachy & $6.45 \pm 2.25$ & $(4.67-10.6)$ & $3.62 \pm 1.83$ & $(1.26-6.41)$ & $1.23 \pm 0.67$ & $(0.35-2.02)$ \\
Orava - Bobrov & $2.24 \pm 0.76$ & $(1.00-3.35)$ & $0.29 \pm 0.36$ & $(\mathrm{ND}-0.85)$ & $0.61 \pm 0.35$ & $(0.25-1.24)$ \\
Sitnianska Lehôtka & $4.32 \pm 1.40$ & $(1.98-6.10)$ & $0.44 \pm 0.58$ & $(\mathrm{ND}-1.45)$ & $0.26 \pm 0.21$ & $(0.01-0.64)$ \\
Suchý vrch & $2.57 \pm 0.85$ & $(1.14-3.61)$ & $1.54 \pm 1.50$ & $(\mathrm{ND}-3.38)$ & $0.35 \pm 0.08$ & $(0.24-0.45)$ \\
\hline
\end{tabular}

\section{Mushroom stems (Boletus reticulatus)}

The amounts of cadmium, lead and mercury recorded in mushroom stems are displayed in Table 3.

Concerning the mushroom stems, Cd content varied from ND to $4.08 \mathrm{mg} \cdot \mathrm{kg}^{-1}$ $\mathrm{DW}, \mathrm{Pb}$ from ND to $14.3 \mathrm{mg} \cdot \mathrm{kg}^{-1} \mathrm{DW}$ and $\mathrm{Hg}$ from 0.01 to $1.17 \mathrm{mg} \cdot \mathrm{kg}^{-1} \mathrm{DW}$ The maximum content, in relation to average amounts, was detected in Nižne Ružbachy for $\mathrm{Cd}\left(2.63 \mathrm{mg} \cdot \mathrm{kg}^{-1} \mathrm{DW}\right)$ and $\mathrm{Pb}\left(6.04 \mathrm{mg} \cdot \mathrm{kg}^{-1} \mathrm{DW}\right)$, and in Malý Lipník (0.72 mg.kg $\left.{ }^{-1} \mathrm{DW}\right)$ for $\mathrm{Hg}$. The minimum Cd concentration was detected in Dobroč $\left(0.34 \mathrm{mg} \cdot \mathrm{kg}^{-1} \mathrm{DW}\right)$ and in Orava-Bobrov for $\mathrm{Pb}\left(0.08 \mathrm{mg} \cdot \mathrm{kg}^{-1} \mathrm{DW}\right)$ and $\mathrm{Hg}\left(0.11 \mathrm{mg} \cdot \mathrm{kg}^{-1} \mathrm{DW}\right)$.

According to the EU limit value, the border limit in edible mushroom (both, cap and stem) is for $\mathrm{Cd} 0.50, \mathrm{~Pb} 1.00$ and $\mathrm{Hg} 0.75 \mathrm{mg} . \mathrm{kg}^{-1} \mathrm{DW}$. In concordance with the EU limits, considering average concentrations, 6 locations (Kolačkov 98\%, Malý Lipník 97\%, Nižné Ružbachy 100\%, Orava-Bobrov 86\%, Sitnianska Lehôtka $90 \%$ and Suchý vrch $60 \%$ ) exceeded the $\mathrm{Cd}$ limit and 3 locations (Kolačkov 98\%, Malý Lipník 67\% and Nižné Ružbachy 100\%) Pb limit. Relating to $\mathrm{Hg}$, all the mushroom stem samples were below the limit.Cadmium values in genus Boletus samples have been reported to be in the ranges $1.00-15.6 \mathrm{mg} \cdot \mathrm{kg}^{-1}$ DW (Kalač and Svoboda, 2000).

The lower cadmium values found in genus Boletus were $0.23 \mathrm{mg} . \mathrm{kg}^{-1} \mathrm{DW}$ (Ouzouni et al., 2009) and $0.34 \mathrm{mg} . \mathrm{kg}^{-1} \mathrm{DW}$ (Yamaç et al., 2007). The cadmium contents in our mushroom samples agree with the lower values reported in the literature.

Table 3 Cadmium, lead and mercury contents in Boletus reticulatus stems ( $\mathrm{n}=48$ )

\begin{tabular}{|c|c|c|c|c|c|c|}
\hline \multirow{2}{*}{ Locality } & \multicolumn{2}{|c|}{ Cd } & \multicolumn{2}{|c|}{$\mathbf{P b}$} & \multicolumn{2}{|c|}{$\mathbf{H g}$} \\
\hline & $\mathrm{AVG} \pm \mathrm{SD}$ & range & $\mathrm{AVG} \pm \mathrm{SD}$ & range & $\mathrm{AVG} \pm \mathrm{SD}$ & range \\
\hline Dobroč & $0.34 \pm 0.10$ & $(0.18-0.47)$ & $0.56 \pm 0.47$ & (ND-1.41) & $0.26 \pm 0.02$ & $(0.24-0.29)$ \\
\hline Kokošovce & $0.24 \pm 0.11$ & $(0.14-0.48)$ & $0.46 \pm 0.33$ & (ND-0.96) & $0.35 \pm 0.15$ & $(0.11-0.67)$ \\
\hline Kolačkov & $2.61 \pm 0.51$ & $(1.83-3.15)$ & $4.12 \pm 1.71$ & $(1.49-6.56)$ & $0.61 \pm 0.10$ & $(0.51-0.75)$ \\
\hline Malý Lipník & $2.43 \pm 1.06$ & $(0.75-4.08)$ & $2.52 \pm 2.48$ & (ND-6.43) & $0.72 \pm 0.15$ & $(0.43-0.92)$ \\
\hline Nižné Ružbachy & $2.63 \pm 0.45$ & $(2.22-3.21)$ & $6.04 \pm 4.22$ & $(2.79-14.3)$ & $0.70 \pm 0.36$ & $(0.22-1.17)$ \\
\hline Orava - Bobrov & $0.81 \pm 0.19$ & $(0.46-1.02)$ & $0.08 \pm 0.12$ & (ND-0.36) & $0.11 \pm 0.02$ & $(0.08-0.14)$ \\
\hline Sitnianska Lehôtka & $2.24 \pm 0.89$ & $(0.65-3.33)$ & $0.32 \pm 0.27$ & (ND-0.83) & $0.13 \pm 0.07$ & $(0.01-0.21)$ \\
\hline Suchý vrch & $0.51 \pm 0.43$ & (ND-1.16) & $0.66 \pm 0.90$ & (ND-2.27) & $0.18 \pm 0.03$ & $(0.13-0.24)$ \\
\hline
\end{tabular}

Note: AVG: average, SD: standard deviation. Contents of selected risk elements (cadmium, lead and mercury) are expressed in mg.kg ${ }^{-1} \mathrm{DW}$

\section{Spearman's correlation test}

Spearman's correlation test (significant level $\mathrm{p}<0.05$ ) was used to determinate the relationship between two variables (soil-cap; soil-stemand cap-stem).The detected relationship between two variables, in terms of cadmium content (Fig. 1), was negative relationship between soil-capand soil-stem, thereby the relationship soil-stem was stronger than soil/cap. Regarding to relationship between stem-cap, there was detecteda positive significant relationship According to these findings we can state that the $\mathrm{Cd}$ from soil passes into stem and is translocated to cap, where it concentrates.

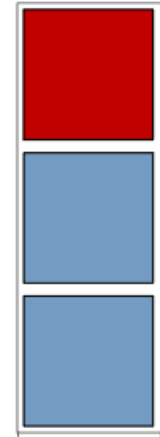

Soil
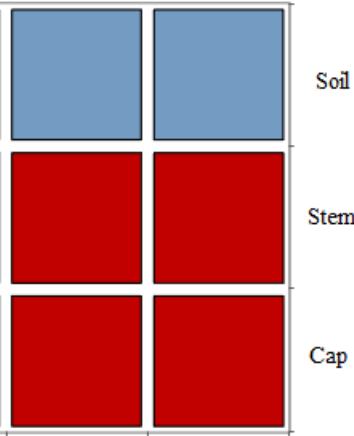

Stem

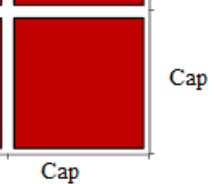

Cap
Figure 1 Relationship between $\mathrm{Cd}$ contents in mushrooms (caps-stems) and underlying soil substrate using a Spearman test

Note:* blue color represent a negative correlation and red color a strong positive correlation, between the variables.

Considering mercury (Fig. 2), there was detected a positive relationship between soil-cap and soil-stem, therewith that the relationshipsoil-stem was stronger than soil-cap, same as at $\mathrm{Cd}$. Regarding to the correlation between stem-cap, there was detected a positive significant relationship.

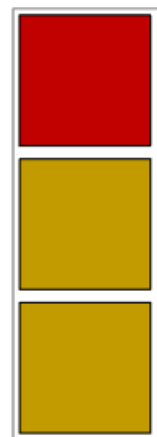

Soi
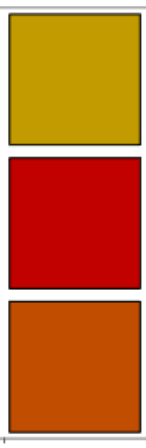

Stem

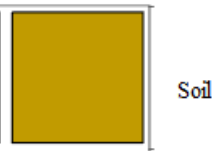

Soil

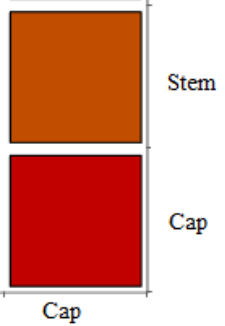

Figure 2 Relationship between $\mathrm{Hg}$ contents in mushrooms (caps-stems) and underlying soil substrate using a Spearman test

Note: $*$ red color represent a strong positive correlation between the variables. As color intensity decreases (orange-yellow), it means that decreases also the relationship between the variables.

Regarding to lead (Fig. 3), there was no relationship found between soil-stem, while the correlation soil-cap was so low, that we can statethat it can be considered as negligible. However, between stem-cap there was found a positive weak correlation. The low mobility of $\mathrm{Pb}$ and its subsequent fast accumulation in stem tissues are the main reasons that $\mathrm{Pb}$ concentrates mainly in stems and is not translocated to caps, as it is in the case of $\mathrm{Cd}$ and $\mathrm{Hg}$. This proves that the negligible correlation of detected $\mathrm{Pb}$ amount in mushroom fruiting bodies is from soil substrate, but the vast majority of it is taken from the atmospheric origin (e.g. smelter-derived dust etc.). 


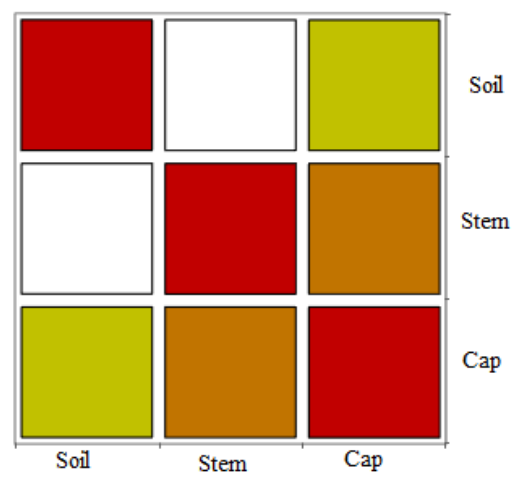

Figure 3 Relationship between $\mathrm{Pb}$ contents in mushrooms (caps-stems) and underlying soil substrate using a Spearman test

Note: ${ }^{*}$ red color represent a strong positive correlation between the variables. As color intensity decreases (orange-yellow), it means that decrease also the relationship between the variables. White color represents that there was no relationship found

\section{CONCLUSION}

Wild growing mushrooms are consumed as a delicacy in many countries Compared with cultivated mushrooms, or vegetables and fruit, the risk element contents in the wild growing species are commonly high, and primarily species dependent. Extensive research has been carried out on trace elements for searching edible wild growing $B$. reticulatus and its underlying soi substrate accumulating high levelsof some risk elements $(\mathrm{Cd}, \mathrm{Pb}$ and $\mathrm{Hg})$, and for investigating the level of selected risk elements. This research was carried out in selected areasof 8 different locations in Slovak republic. As mentioned, these eight locations belong to $1^{\text {st }}$ (regions with undisturbed environment) and $2^{\text {nd }}$ (regions with moderately disturbed environment) environmental region quality. This study showed that the analyzed mushroom samples were contaminated with $\mathrm{Cd}$ and $\mathrm{Pb}$, according to stems, and regarding to caps with all selected elements $(\mathrm{Cd}, \mathrm{Pb}$ and $\mathrm{Hg})$. It has been revealed that the amounts of risk elements are mainly concentrated in mushroom caps. Considering the underlying soil substrate, all sampleswere contaminated with $\mathrm{Cd}$.

Spearman's correlation test determinate the relationship between soil-mushroom (both, stem and cap), related to $\mathrm{Cd}$ and $\mathrm{Hg}$. Based on thiswe can proclaim that the detected amounts of these two elements in mushrooms accumulated mainly from soil. Considering $\mathrm{Pb}$ content, Spearman's correlation test found a relationship only between stem-cap, so it can be stated that the detected lead concentration in mushrooms reached principally from atmosphere, thus not from soil. The results confirmed that studied mushrooms, as well as soil substrates,were contaminated with risk elements. As well was confirmed the transport of analyzed trace elements from the soil $(\mathrm{Cd}$ and $\mathrm{Hg}$ )and atmosphere $(\mathrm{Pb})$ to mushrooms (stemcap).

Acknowledgments: This work was supported by the project VEGA No. $1 / 0591 / 18$.

\section{REFERENCES}

Act No. 220/2004 Coll. Of Laws of Slovak Republic. On the conservation and use of agricul- tural land, amending the Act No. 245/2003 Coll. on integrated pollution prevention and control, amending and supplementing of certain acts, as amended.

ADDINSOFT (2014) XLSTAT, Analyse de données et statistique avec MS Excel. Addinsoft, New York.

ANGELOVIČOVÁ, L., \& FAZEKAŠOVÁ, D. (2014). Contamination of the soil and water environment by heavy metals in the former mining area of Rudňany (Slovakia). Soil and water research, 9(1), 18-24 https://doi.org/10.17221/24/2013-SWR

BAHADORI, M.B., SARIKURKCU, C., YALCIN, O.U., CENGIZ, M. GUNGOR, H. (2019). Metal concentration, phenolics profiling, and antioxidant activity of two wild edible Melanoleuca mushrooms ( $M$. cognata and $M$. stridula). https://doi.org/10.1016/j.microc.2019.104172

DEMKOVA, L., JEZNÝ, T., \& BOBULSKÁ, L. (2017). Assessment of soil heavy metal pollution in a former mining area-before and after the end of mining activities. Soil and Water Research, 12(4), 229-236. https://doi.org/10.17221/107/2016-SWR

FALANDYSZ, J., KAWANO, M., ŚWIECZKOWSKI, A., BRZOSTOWSKI, A., DADEJ, M. (2003). Total mercury in wild-grown higher mushrooms and underlying soil from Wdzydze Landscape Park, Northern Poland. Food chemistry, 81(1), 21-26. https://doi.org/10.1016/S0308-8146(02)00344-8
IŞILOĞLU, M., YILMAZ, F., \& MERDIVAN, M. (2001). Concentrations of trace elements in wild edible mushrooms. Food Chemistry, 73(2), 169-175. https://doi.org/10.1016/S0308-8146(00)00257-0

KALAČ, P., \& SVOBODA, L. (2000). A review of trace element concentrations in edible mushrooms. Food chemistry, 69(3), 273-281. https://doi.org/10.1016/S0308-8146(99)00264-2

KOMÁREK, M., CHRASTNÝ, V., \& ŠTÍCHOVÁ, J. (2007). Metal/metalloid contamination and isotopic composition of lead in edible mushrooms and forest soils originating from a smelting area. Environment international, 33(5), 677-684 https://doi.org/10.1016/j.envint.2007.02.001

LIU, Y., CHEN, D., YOU, Y., ZENG, S., LI, Y., TANG, Q., \& SU, Y. (2016) Nutritional composition of boletus mushrooms from Southwest China and their antihyperglycemic and antioxidant activities. Food chemistry, 211, 83-91. https://doi.org/10.1016/j.foodchem.2016.05.032

MELGAR, M. J., ALONSO, J., \& GARCÍA, M. A. (2009). Mercury in edible mushrooms and underlying soil: bioconcentration factors and toxicological risk. Science of the Total Environment, 407(20), 5328-5334. https://doi.org/10.1016/j.scitotenv.2009.07.001

OUZOUNI, P. K., PETRIDIS, D., KOLLER, W. D., \& RIGANAKOS, K. A (2009). Nutritional value and metal content of wild edible mushrooms collected from West Macedonia and Epirus, Greece. Food Chemistry, 115(4), 1575-1580. https://doi.org/10.1016/j.foodchem.2009.02.014

RONCERO-RAMOS, I., \& DELGADO-ANDRADE, C. (2017). The beneficial role of edible mushrooms in human health. Current Opinion in Food Science, 14 122-128. https://doi.org/10.1016/j.cofs.2017.04.002

ŠIRIĆ, I., ŽURGA, P., BARKIĆ, D., \& MALENICA STAVER, M. (2016). Trace element contents in the edible mushroom boletus edulis bull. Ex fries. $\begin{array}{llll}\text { Agriculturae } \quad \text { Conspectus } & \text { Scientificus, } & \text { 80(4), } & \text { 223-227. }\end{array}$ https://hrcak.srce.hr/156931

TÜZEN, M. (2003). Determination of heavy metals in soil, mushroom and plant samples by atomic absorption spectrometry. Microchemical Journal, 74(3), 289. 297. https://doi.org/10.1016/S0026-265X(03)00035-3

YAMAÇ, M., YILDIZ, D., SARIKÜRKCÜ, C., CELIKKOLLU, M., \& SOLAK, M. H. (2007). Heavy metals in some edible mushrooms from the Central Anatolia, Turkey. Food Chemistry, 103(2), 263-267. https://doi.org/10.1016/j.foodchem.2006.07.041 